\title{
Comparison of propranolol and LB 46 (prinodolol) on hyperthyroid tachycardia
}

\author{
A. G. Arbab \\ P. TURNER \\ B.Sc., M.B., B.S. \\ M.D., B.Sc., M.R.C.P. \\ Division of Clinical Pharmacology, \\ Medical Professorial Unit, \\ St Bartholomew's Hospital, London, E.C.1
}

\begin{abstract}
Summary
LB 46 (prinodolol) a $\beta$-adrenergic receptor blocking drug which is more potent than propranolol in euthyroid subjects, is less effective in inhibiting hyperthyroid tachycardia. This is probably due to its intrinsic sympathomimetic activity.
\end{abstract}

CARDIOVASCULAR symptoms in hyperthyroidism are due in part to increased responsiveness to adrenergic stimulation (Turner, 1970; Turner \& Hill, 1968; Leak, 1970). The observation that the adrenergic neurone blocking drugs, reserpine and guanethidine reduce many of the symptoms of experimental and spontaneous hyperthyroidism suggested that adrenergic mechanisms are important in the production of most of the peripheral cardiovascular manifestations of this condition (Canary et al., 1959; Gaffney, Braunwald \& Kahler, 1961; Goldstein \& Killip, 1965).

Propranolol, a $\beta$-adrenoceptor blocking agent, in addition to its therapeutic effect on cardiac arrhythmias due to other causes, has been shown effectively to control tachycardia in hyperthyroidism (Turner, Granville-Grossman \& Smart, 1965; Parsons \& Jewitt, 1967; Rowlands, Howitt \& Markham, 1965).

Another $\beta$-blocking drug, LB 46 (prinodolol) reduces isoprenaline and exercise-induced tachycardia in much smaller doses than propranolol but possesses intrinsic sympathomimetic activity (Hill \& Turner, 1968; Frick, Heikkila \& Luomanmäki, 1970).

In this paper, an attempt was made to compare the $\beta$-blocking effects of LB 46 and propranolol on hyperthyroid tachycardia.

\section{Method}

Eight in-patients, ore male and seven females, between 27 and 60 years of age, were selected, having all the characteristic signs and symptoms of hyperthyroidism and with confirmatory laboratory data. All were in sinus rhythm. They were given propranolol 5 and $10 \mathrm{mg}$, LB 460.5 and $1.0 \mathrm{mg}$ or normal saline intravenously, under double blind conditions at the same time of day over 5 days. The order of administration of drugs was randomized but smaller doses were always given before the larger.

Patients were lying comfortably in bed, while their resting heart rates were recorded with a Cambridge direct writing electrocardiograph for $5 \mathrm{~min}$ at $1 \mathrm{~min}$ intervals. Immediately after taking the last record of heart rate, the drug was injected intravenously slowly over a period of $1 \frac{1}{2} \mathrm{~min}$. At the end of the injection and subsequently after each minute for $5 \mathrm{~min}$ and finally at the end of the tenth min, heart rates were recorded as above. This procedure was followed on each of the 5 days with each patient. The data were analysed using Student's ' $t$ ' test for comparison.

\section{Results}

The results were analysed in two ways, namely using the final heart rates at the tenth min after injection and secondly, the fall in heart rates from mean pretreatment values to that of the tenth min post injection. The mean values are shown in Table 1. Statistical analysis (Tables 2 and 3) showed that both propranolol and LB 46 produced a significant fall in heart rate when compared with normal saline, but that propranolol was significantly more effective than both doses of LB 46.

When the final heart rates were considered, those after propranolol were significantly lower than those after normal saline, while those after LB 46 were not significantly different $(0.5 \mathrm{mg})$ or only marginally so $(1 \cdot 0 \mathrm{mg})$.

\section{Discussion}

LB 46 is a more potent $\beta$-adrenergic receptor blocking drug than propranolol. In animal experiments, ratios varying between ten and forty times that of propranolol have been given (Giudicelli, Schmitt \& Boissier, 1969; Saameli, 1967) while in normal human volunteers Hill \& Turner (1969) found it to be between twenty and forty times more 
TABLE 1. The mean final heart rates (beats/min $\pm S E$ ) at the tenth min after injection, and the mean falls in heart rate (beats/min $\pm S E$ ) after administration of LB 46, propranolol and normal saline

\begin{tabular}{lcccc}
\hline & $\begin{array}{c}\text { Mean final } \\
\text { heart rate }\end{array}$ & SE & $\begin{array}{c}\text { Mean fall in } \\
\text { heart rate }\end{array}$ & SE \\
\hline Normal saline & 94.5 & \pm 3.2 & 3.6 & \pm 1.65 \\
LB 46 0.5 mg & 90.2 & \pm 4.8 & 13.6 & \pm 1.88 \\
LB 46 1.0 mg & 88.9 & \pm 3.51 & 12.9 & \pm 4.77 \\
Propranolol 5 mg & 83.1 & \pm 1.74 & 22.7 & \pm 3.56 \\
Propranolol 10 mg & 83.9 & \pm 2.04 & 19.0 & \pm 2.07 \\
\hline
\end{tabular}

TABLE 2. Comparison of the mean falls in heart rate of hyperthyroid patients after LB 46, propranolol and normal saline

\begin{tabular}{lcccc}
\hline \multicolumn{1}{c}{ Treatment } & $d$ & SE & $t$ & $P$ \\
\hline Normal saline $v$ propranolol $5 \mathrm{mg}$ & 19.1 & \pm 3.7 & 5.16 & $<0.01$ \\
Normal saline $v$ propranolol 10 mg & 15.4 & \pm 2.38 & 6.47 & $<0.01$ \\
Normal saline $v$ LB 46 0.5 mg & 10.0 & \pm 3.27 & 3.06 & $<0.02$ \\
Normal saline $v$ LB 46 1.0 mg & 9.3 & \pm 3.79 & 2.44 & $<0.05$ \\
Propranolol 5 mg $v$ LB 46 0.5 mg & 9.1 & \pm 4.37 & 2.08 & $<0.1$ \\
Propranolol 5 mg $v$ LB 46 1.0 mg & 9.8 & \pm 3.84 & 2.57 & $<0.05$ \\
Propranolol 10 mg $v$ LB 46 1.0 mg & 6.1 & \pm 3.19 & 1.91 & $<0.1$ \\
\hline
\end{tabular}

TABLE 3. Comparison of the mean final heart rates of hyperthyroid patients after LB 46, propranolol and normal saline

\begin{tabular}{lcllc}
\hline \multicolumn{1}{c}{ Treatment } & $d$ & SE & $t$ & $P$ \\
\hline Normal saline $v$ propranolol $5 \mathrm{mg}$ & 11.4 & \pm 3.2 & 3.56 & $<0.01$ \\
Normal saline $v$ propranolol $10 \mathrm{mg}$ & 10.6 & \pm 2.88 & 3.64 & $<0.01$ \\
Normal saline $v$ LB 46 0.5 mg & 4.3 & \pm 4.1 & 1.05 & $\mathrm{NS}$ \\
Normal saline $v$ LB $461.0 \mathrm{mg}$ & 5.6 & \pm 2.42 & 2.31 & 0.05 \\
Propranolol 5 mg $v$ LB 46 0.5 mg & $7 \cdot 1$ & \pm 5.15 & 1.38 & $\mathrm{NS}$ \\
Propranolol 10 mg $v$ LB 46 1.0 mg & 5.0 & \pm 2.78 & 1.8 & NS \\
\hline
\end{tabular}

effective in inhibiting isoprenaline and exerciseinduced tachycardia when given orally.

Preliminary intravenous studies with hyperthyroid patients suggested that a ratio of ten was more likely to apply and for this reason 0.5 and $1.0 \mathrm{mg}$ LB 46 were compared with 5 and $10 \mathrm{mg}$ of propranolol in this definitive study. However, in this study although both LB 46 and propranolol significantly reduced hyperthyroid tachycardia, propranolol was significantly more effective than LB 46.

More recent normal volunteer studies (Arbab \& Turner, unpublished observations) show that $0.25 \mathrm{mg}$ LB 46 inhibited isoprenaline-induced tachycardia to a similar extent as propranolol $5 \mathrm{mg}$ when given intravenously, and $0.5 \mathrm{mg}$ was markedly more effective, so that in terms of $\beta$-receptor blockade both 0.5 and $1.0 \mathrm{mg}$ may be considered supramaximal.

These results are in accord with those obtained with other $\beta$-receptor blocking drugs including oxprenolol, practolol (Turner \& Hill, 1968) and alprenolol (Turner, 1970) which indicate that compounds possessing intrinsic sympathomimetic activity are inferior in the control of hyperthyroid tachycardia to those such as propranolol and sotalol (Ekue, Lowe \& Shanks, 1970), which do not. $\stackrel{2}{\stackrel{2}{*}}$ It is probable that the increased responsiveness to $\frac{3}{3}$ adrenergic stimulation seen in hyperthyroidism and the increased intrinsic activity of the tissues in this condition may be explained in terms of increased adenylcyclase in the tissues with a consequent rise in 3 cyclic AMP (Robison, Butcher \& Sutherland, 1967).

\section{Acknowledgments}

We thank the physicians of St Bartholomew's Hospital for a'lowing us to study their patients, the staff who co-o operated with us and Sandoz Products Ltd and ICI Ltd who kindly provided LB 46 and propranolol respectively. T A.G.A. is supported by a Colombo Plan Scholarship.

\section{References}

Canary, J.J., Schaff, M., Duffy, B.J. \& Kyle, L.H. (1959)へ The effects of oral and intramuscular administration of N reserpine in thyrotoxicosis. New England Journal of Medicine, 257, 435.

Ekue, J.M.K., Lowe, D.C. \& Shanks, R.G. (1970) Comeo parison of the effects of propranolol and MJ 1999 on cardiac beta-adrenoceptors in man. British Journal of Pharmacology and Chemotherapy, 38, 546.

Frick, M.H., HeikKILA \& Loumanmaki, K. (1970) Haemodynamics of the new beta adrenergic antagonist LB 46 in man. Pharmacologia clinica, 2, 134. 
Gaffney, T.E., Braunwald, E. \& Kahler, R.L. (1961) Effects of guanethidine on tri-iodothyronine-induced hyperthyroidism in man. New England Journal of Medicine, $265,16$.

Giudicelli, J.F., Sсhмitt, H. \& Boissier, J.R. (1969) Studies on dl-4-(2-hydroxy-3-isopropylaminopropoxy)indole (LB 46). A new potent beta adrenergic blocking drug. Journal of Pharmacology and Experimental Therapeutics, 168, 116.

Goldstein, S. \& Killip, T. (1965) Catecholamine depletion in thyrotoxicosis. Effect of guanethidine on cardiovascular dynamics. Circulation, 31, 219.

Hill, R.C. \& Turner, P. (1969) Preliminary investigations of a new beta-adrenoceptive receptor blocking drug, LB 46, in man. British Journal of Pharmacology and Chemotherapy, 36, 368.

Hill, R.C. \& TURNer, P. (1968) The effects of a new betaadrenoceptive receptor blocking drug on heart rate in man. British Journal of Pharmacology and Chemotherapy, 32, 663.

HowitT, G. \& Rowlands, D.J. (1966) Beta-sympathetic blockade in hyperthyroidism. Lancet, i, 628.

LEAK, D. (1970) The Thyroid and the Autonomic Nervous System, pp. 24-29. William Heinemann Medical Books Ltd, London.
Parsons, V. \& JewitT, D. (1967) Beta-adrenergic blockade in the management of acute thyrotoxic crisis, tachycardia and arrhythmias. Postgraduate Medical Journal, 43, 756.

Robison, G.A., Butcher, R.W. \& Sutherland, E.W. (1967) Adenyl cyclase as adrenergic receptor. Annals of the New York Academy of Sciences, 139, 703.

Rowlands, D.J., HowitT, G. \& Markham, P. (1965) Propranolol (Inderal) in disturbance of cardiac rhythm. British Medical Journal, 1, 891.

SAAMELI, K. (1967) Comparative study with beta-blockers and quinidine. Helvetica physiologica et pharmacologica acta, $25,432$.

TURNER, P. (1970) The role of beta-receptor antagonists in hyperthyroidism. Postgraduate Medical Journal, 47, (Jan. Suppl. 97.)

TURNER, P. (1970) Alprenolol and propranolol in hyperthyroid tachycardia. British Journal of Pharmacology and Chemotherapy, 40, 146.

Turner, P. \& Hill, R.C. (1968) A comparison of three beta-adrenergic receptor blocking drugs in thyrotoxic tachycardia. Journal of Clinical Pharmacology and Journal of New Drugs, 8, 268.

Turner, P., Granville-Grossman, K.L. \& Smart, J.V. (1965) Effect of adrenergic receptor blockade on the tachycardia of thyrotoxicosis and anxiety state. Lancet, ii, 1316. 